Língua e Literatura, n. 20, p. 81-102, 1992/1993.

\title{
A CIDADE MODERNA E A BUSCA DE UM TERRITÓRIO PARA A POESIA
}

Vicência Maria Freitas Jaguaribe*

Canto da minha maneira. Que me importa si me não entendem? Não tenho forças bastantes para me universalizar? Paciência. Com o vário alaúde que construí, me parto por essa selva selvagem da cidade. Como o homem primitivo cantarei a princípio só. Mas canto é agente simpático: faz renascer na alma dum outro predisposto ou apenas sinceramente curioso e livre, o mesmo estado lírico provocado em nós por alegrias, sofrimentos, ideais. Sempre hei-de achar também algum, alguma que se embalarão à cadência libertária dos meus versos. Nesse momento: novo Anfião moreno e caixa-d'óculos, farei que as próprias pedras se reúnam em muralhas à magia do meu cantar. E dentro dessas muralhas esconderemos nossa tribo.

(Mário de Andrade. "Prefácio interessantíssimo") 

poesia. Ĺngua e Literatura, n. 20, p. 81-102, 1992/1993.

RESUMO: A leitura dos seguintes poemas de Mário de Andrade: "Rua de São Bento" "Paisagem $\mathrm{N}^{\circ} 1^{\prime \prime}$, "Paisagem $\mathrm{N}^{\circ} 2$ " "Paisagem $\mathrm{N}^{\circ} 3$ " e "Paisagem $\mathrm{N}^{\circ} 4$ ", sugere-nos a busca de um locus poesiae, pelo eu-lírico, que rejeita a cidade moderna como esse locus. Numa dialética de atraçāo e repulsa, o eu-lírico termina por aceitar a metrópole como o território da "minha Loucura" e chega até $a$ integrar-se nela.

Palavras-chave: Metrópole, locus poesiae, atração, repulsa.

\section{Introdução}

Os tempos modernos, por suas próprias características, implodem os conceitos estéticos vigentes no mundo ocidental até o final do século XIX. Baudelaire vai ser o arauto da nova estética, ao publicar, já em 1857, o seu Les Fleurs du Mal, que inaugura um novo sentido de poesia a ser seguido pelos poetas do século XX. Com ele, e a partir dele, a lírica se despersonaliza, isto é, deixa de nascer da unidade de poesia e pessoa empírica; a temática muda de endereço e, agora, abandonamse os temas amenos, voltando-se o poeta para o mísero, o decadente, o mau, o noturno; exploram-se as potencialidades mágicas da linguagem; descobre-se um novo locus poesiae: a cidade comercializada e dominada pela técnica.

Com os ecos de Baudelaire, Rimbaud, Verlaine e Mallarmé, com a força das vanguardas européias do início do século, a nova lírica impõe-se no mundo ocidental, chegando ao Brasil na esteira do movimento modernista. Mário de Andrade, com Paulicéia Desvairada, publicado em 1922, rompe com a tradição, principalmente com a tradição parnasiana brasileira: "O passado é lição para se meditar, não para reproduzir" (Prefácio Interessantíssimo).

Tomando a cidade moderna, isto é, a cidade de São Paulo, como tema de sua lírica, Mário revela-se em tensão com esse novo espaço, que o atrai, mas ao mesmo tempo o amedronta. Agora, com Mário de Andrade, a lírica brasileira começa a cantar o dinamismo do progresso, as multidões anônimas, o mundo da técnica e do comércio; começa a denunciar os males do moderno espaço citadino a ambição, a inveja, as doenças, a natureza degradada, o desrespeito, enfim, pela pessoa humana e pelo espaço natural. O poeta, então, para poder incluir em seu canto esse novo complexo, para poder entender esse topos esfacelado e ambíguo, disfarça-se e esconde-se sob variadas máscaras, procurando, ao intentar a busca da identidade desse novo mundo, encontrar a identidade do homem moderno, portanto, a sua própria identidade, uma vez que ele também se esfacelou e perdeu seu caráter.

Os poemas de Paulicéia Desvairada debruçam-se sobre a realidade de São Paulo, e seu autor procura, encantado com a uiara enganosa, ver narcisicamente sua face na face da cidade. Mas a relação não é tranqüila, de modo que, se no poema que abre a obra, podemos ler o verso "São Paulo! Comoção de minha vida...", mais adiante, no poema "Tu", estarrecemo-nos diante da seguinte estrofe: 
Oh! Incendiária dos meus aléns sonoros!

Tu és o meu gato preto!

Tu me esmagaste nas paredes do meu sonho!

Este sonho medonho!

É, portanto, com o objetivo de captar essa dialética de atração e repulsa do eu-lírico de Paulicéia Desvairada em relação à cidade de São Paulo; como também com a intenção de mostrar que a rejeição da cidade como o locus poesiae vai progressivamente desaparecendo, até que o eu-lírico a aceita como motor de sua inspiração poética, que nos propomos fazer uma leitura de cinco poemas do livro "Rua de São Bento", "Paisagem $\mathrm{N}^{\circ} 1$ ", "Paisagem No 2 ", "Paisagem $\mathrm{N}^{\circ} 3$ " e "Paisagem $\mathrm{N}^{\circ} 4$ ", procurando encontrar nos cinco uma significação que os aproxime.

Orientamos este trabalho pelo estudo que Hugo Friedrich faz sobre a poesia moderna, em Estrutura da lírica moderna; pelo artigo de Marlene de Castro Correia, publicado na revista Tempo Brasileiro e intitulado $A$ moderna lírica brasileira: Mário de Andrade; pela obra Figuração da intimidade, de João Luiz Lafetá, dentre outros estudos, todos devidamente relacionados ao final deste trabalho.

Esta tentativa de leitura de poemas de Mário de Andrade nos soou como um desafio, como uma busca da chave, ou das chaves de sua poética, somente alcançada por aqueles que não têm "olhos mudos", pois, para Mário,

(...) versos não se escrevem para leitura de olhos mudos. Versos cantam-se, urram-se, choram-se. Quem não souber cantar não leia Paisagem $N^{\circ} 1$. Quem não souber urrar não leia

Ode ao Burguês. Quem não souber rezar, não leia

Religião. Desprezar: A Escalada. Sofrer:

Colloque Sentimental. Perdoar: a cantiga do berço, um dos solos de Minha Loucura, das Enfibraturas do Ipiranga. Não continuo.

Repugna-me dar a chave de meu livro. Quem for como eu tem essa chave.

\section{O trovador brasileiro da modernidade}

Publicando Paulicéia Desvairada, em 1922, Mário de Andrade inaugura, no Brasil, o aproveitamento do espaço cultural do século XX como motivo de poesia, opondo-se a uma estética ultrapassada que teimava em sustentar-se, a despeito das transformações ocorridas no mundo. É o que lembra Marlene de Castro Correia (1985), intertextualizando com Olavo Bilac que, em seu conhecido "A um poeta", considerou "estéril" para o fazer poético, o espaço urbano: "Longe do estéril turbilhão da rua,/ Beneditino, escreve!" 

poesia. Língua e Literatura, n. 20, p. 81-102, 1992/1993.

Podemos considerar Bilac, nesse metapoema, um porta-voz do que se convencionou chamar de poética tradicional, uma vez que a cidade cosmopolita ainda não se havia transformado em motivo de inspiração, a não ser para algumas figuras excepcionais, como Baudelaire, o criador da poesia moderna. Mas a expressão "poeta da modernidade" que pode designar Baudelaire, pode também ser um rótulo a congregar os escritores que, a partir do autor de Les Fleurs du Mal, tiveram "a capacidade de ver no deserto da metrópole não só a decadência do homem, mas também de pressentir uma beleza misteriosa, não descoberta até então" (FRIEDRICH, 1991: 35).

É importante considerar os elementos que Baudelaire incluiu em suas reflexões sobre a modernidade. No poeta francês, a modernidade não se resolve somente por categorias negativas: é algo muito mais complexo, que soma categorias negativas e positivas, as quais se manifestarão num movimento de atração e repulsa do eu-lírico em relação ao mundo das metrópoles. $\mathrm{O}$ feio e o degradante que se constroem na cidade moderna, cortada pelo asfalto e pela iluminação artificial; marcada pelas altas construções, pelas máquinas a vapor, pelo progresso, enfim, que relega a figura humana a um segundo plano onde impera a solidão e onde se dá a "atrofia do espírito" o "decaimento progressivo da alma" e o "predomínio progressivo da matéria", nas palavras do próprio Baudelaire (Apud FRIEDRICH, 1991: 43), esse feio e degradante estimulam a produção poética.

Abandonar os temas tradicionalmente considerados poéticos, e eleger o espaço urbano moderno como motivo de poesia, implica, para os poetas da modernidade, herdeiros de Baudelaire, uma mudança de perspectiva, denunciada principalmente pela adoção de uma linguagem nova, caracterizada pela desarticulação e pelo obscurantismo; de um novo conceito de beleza que inclui o feio, o grotesco e o desagradável; que revela um eu-lírico de consciência fragmentada, em busca de identidade, escondendo-se por trás de variadas máscaras.

No Brasil, Mário de Andrade é o poeta moderno e modernista por excelência, ao tomar a cidade de São Paulo como motivo poético de sua primeira obra concebida dentro dos cânones (ou da ausência de cânones?) das novas orientações artísticas. É uma São Paulo que está longe de apresentar as características da Paris baudelaireana do Segundo Império, mas que, para o poeta, já se apresenta como "a grande boca de mil dentes", onde "Giram homens fracos, baixos, magros... / Serpentinas de entes frementes a se desenrolar"

Em Paulicéia Desvairada, Mário de Andrade intenta uma busca de identidade tanto da cidade quanto dele próprio, de modo que a cidade, um retrato de seu eu despedaçado, aparece paradoxal, caótica, arlequinal, num reflexo de seu desvairismo, o que se comprova fazendo-se um cotejo entre os versos de "Inspiração":

(1) Os poemas de Paulicéia Desvairada citados neste trabalho estão de acordo com as Poesias completas: Mário de Andrade, edição crítica de Diléa Zanotto Manfio. Belo Horizonte: Itatiaia; São Paulo: Editora da Universidade de São Paulo, 1987. Os versos transcritos nesta página são do poema "Os Cortejos". Sempre que forem citados, os versos trarão a indicação do poema de que foram transcritos. 

poesia. Língua e Literatura, n. 20, p. 81-102,.1:992/1993.

"Arlequinal!... Trajes de losangos... Cinza e ouro... / Luz e bruma... Forno e inverno morno...", que se referem à cidade, e os versos de "O Trovador": "As primaveras de sarcasmo / intermitentemente no meu coração arlequinal...", que obviamente dizem respeito aos sentimentos do eu-lírico. Tanto é que ele diz a Augusto Meyer: "me parece que o desvairado era mesmo eu" (Apud LAFETÁ, 1986: 19). Ele e a cidade eram um só, ou a Paulicéia era uma extensão de seu eu; por conseguinte tem razão Lafetá (Ibidem, p. 19), quando reconhece ser uma "tarefa de Narciso" essa tentativa andradeana de retratar-se no rosto da cidade.

José Paulo Paes (1988) chama a atenção para a simetria existente entre "a tumultuosa interioridade do poeta e a não menos tumultuosa exterioridade da sua Paulicéia", alertando para o fato de ser esta uma simetria dialética, uma vez que se realiza não só pelas semelhanças, mas também pelas diferenças.

É a mesma complexidade constatada na relação de Baudelaire com a metrópole moderna. Mário de Andrade, em seu relacionamento problemático com São Paulo, revela-se em um movimento de atração e repulsa que se expressa em versos como estes, dos poemas "Inspiração" e "Os Cortejos":

São Paulo! Comoção de minha vida...

Horriveis as cidades!

Vaidades e mais vaidades...

Nada de asas! Nada de poesia! Nada de alegria!

ou, então, os seguintes, de "Paisagem n ${ }^{\circ} 4$ " e "Tu":

Oh! este orgulho máximo de ser paulistamente!!!

Gosto dos teus desejos de crime turco

E das tuas ambições retorcidas como roubos!

Amo-te de pesadelos taciturnos

Materialização da Canaã do meu Poe...

Observe-se que, nos quatro versos transcritos do poema "Tu" ressoa uma significação extremamente paradoxal, em que se manifesta o modelo labiríntico de linguagem de que nos fala Lafetá (Ibidem, p. 19) recorrendo a Nietzche. Para o filósofo alemão, o labirinto nos serviria de modelo, caso quiséssemos criar uma arquitetura em consonância com nosso tipo de alma. E foi esse modelo nietzcheano que a vanguarda adotou e que se manifesta em muitos poemas de Paulicéia Desvairada, mas com a máxima força em "Tu" Nos versos desse poema, a cidade de São Paulo assume, ao mesmo tempo, as características de "fidalga" e de "barregã"; é uma "Lady Macbeth feita de névoa fina"; paradoxalmente, é "madrasta" a"irmã"; mas, principalmente, é a fatal atração que leva o eu-lírico à ruína: 
Oh! Incendiária dos meus aléns sonoros!

Tu és o meu gato preto!

Tu me esmagaste nas paredes do meu sonho!

Este sonho medonho!

\section{O trovador arlequinal}

João Luiz Lafetá, em Figuração da intimidade, obra já citada neste trabalho, considera que a criação poética de Mário de Andrade espelha o desenvolvimento das linhas-mestra do Modernismo e, portanto, da história cultural brasileira entre 22 e 45 . Atribui a Mário diferentes máscaras, que seriam uma espécie de roupagem usada pelo poeta para expressar suas reflexões sobre os vários momentos do movimento ideológico da burguesia brasileira. Essas máscaras seriam as do trovador arlequinal; do poeta aplicado; da diversidade em busca da unidade; do espelho sem reflexo e do poeta político.

A primeira máscara - a do trovador arlequinal - corresponde ao momento de criação das obras Paulicéia Desvairada e Losango Cáqui, e mostra um eulírico sentimental e zombeteiro, que encarna o espírito da modernidade, com suas contradições. Está claro que a denominação de trovador arlequinal decorre da imagem de Arlequim, que o autor usa nada menos do que onze vezes nos poemas de Paulicéia Desvairada.

O Arlequim, como sobejamente se sabe, funciona como símbolo do irresoluto e do incoerente; de alguém sem princípios e sem caráter (no sentido em que Mário de Andrade classifica Macunaíma: "o herói sem nenhum caráter"), de um ser que não consegue individualizar-se, personalizar-se. Sua indumentária é bem a evocação dessas qualidades: uma roupa feita de pedaços de pano na forma triangular e de cores variadas; uma máscara negra a esconder-lhe o rosto; e um sabre de madeira. A disposição dos pedaços de pano em xadrez de sua roupa sugere um ser confuso, sem personalidade, que não consegue libertar-se da confusão de desejos, projetos e possibilidades. Portanto o Arlequim reflete não só a figura do poeta um homem facetado à procura de sua própria identidade -, como também a pluralidade da cultura brasileira, a sua falta de "caráter" $\mathrm{O}$ trovador arlequinal é, então, um ser plural, multifacetado, que procura desesperadamente sua própria identidade e a identidade de seu povo. A máscara de Arlequim, uma das muitas máscaras que o poeta usa, diz respeito ao problema da sinceridade, tão importante para ele, que "sua obra parece, toda ela, girar em torno da dialética da sinceridade e do cabotinismo" (LAFETÁ, op. cit.). A máscara não simplesmente esconde a verdadeira personalidade do poeta; é muito mais: ela lhe empresta uma outra personalidade, faculta-lhe uma outra visão de mundo, possibilitando-lhe mais uma oportunidade de encontrar-se a si próprio e determinar o verdadeiro caráter do povo brasileiro. 
poesia. Língua e Literatura, n. 20, p. 81-102, 1992/1993.

Paulicéia Desvairada é uma obra composta de vinte e dois poemas, um prefácio - o famoso Prefácio Interessantíssimo - e um irônico oferecimento de Mário de Andrade a Mário de Andrade, escrito em linguagem antiga, com o tratamento de segunda pessoa do plural, linguagem que parece ironicamente desautorizar o vanguardismo do livro. Dos vinte e dois poemas, quatro se intitulam "Paisagem", devidamente numeradas - "Paisagem $\mathrm{N}^{\circ} 1$ ", "Paisagem $\mathrm{N}^{\circ} 2$ ", "Paisagem $\mathrm{N}^{\circ} 3$ " "Paisagem $\mathrm{N}^{\circ} 4$ "

Nesses quatro poemas, como em quase todos os poemas do livro, a inspiração é claramente a cidade de São Paulo, que se descortina ante os olhos do leitor, desde seu aspecto climático até seus problemas econômicos e sociais. Daí a estranheza do título dos poemas - Paisagem -, palavra cujo significado dicionarizado está mais ligado aos elementos naturais. Talvez o significado latente nesse título seja um outro, que exige uma recorrência ao seu sentido etimológico. Paisagem é cognato de país e vem do latim pagus - $i$, pelo francês paysage. Assim, a Paulicéia retratada nesses poemas, por processo metonímico, deixa de ser apenas a cidade natal do poeta para se transformar na própria nação brasileira, que se desenha, aos olhos do eu-lírico e do leitor, em toda a sua complexidade, suas contradições, suas mil faces descaracterizadoras, seu traje de Arlequim.

É importante notar que, nas quatro Paisagens, arma-se um jogo dialético entre a primeira e a terceira pessoas do discurso, sendo que a primeira pessoa, tão

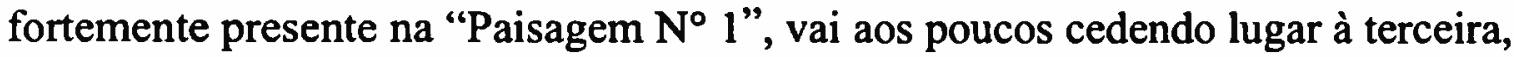
até desaparecer quase totalmente na "Paisagem $\mathrm{N}^{\circ} 4$ ", camuflando a figura do eulírico. O que se percebe nesse jogo é uma progressiva assimilação do eu-lírico pela cidade, acabando aquele por se confundir com esta, desaparecendo assim a forma lingüística que o representa, a primeira pessoa do singular. Resta apenas a terceira pessoa - a cidade -, o que nos sugere o mergulho de um Narciso enamorado de si mesmo, em busca de sua própria imagem.

A leitura das quatro paisagens, que pretendemos fazer, parece-nos completar-se com a leitura de um outro poema de Paulicéia Desvairada, o quinto, na ordem em que aparece no livro: "Rua de São Bento", o qual precede as quatro paisagens e traz, como em uma chamada prévia, elementos importantes retomados nos outros quatro. Por outro lado, "Rua de São Bento" reflete, como nenhum outro poema de Paulicéia Desvairada, aquele movimento de atração e repulsa do eulírico em relação à cidade cosmopolita, de que já falamos anteriormente, e que é uma marca do poeta moderno.

Leremos os cinco poemas como uma unidade, tentando encontrar neles uma única significação, que ganha corpo progressivamente. Esses cinco poemas revelam a busca da inspiração poética na cidade moderna, empreendida pelo sujeitolírico. Essa busca se inicia na "Rua de São Bento", com uma viagem marítima, através da qual o sujeito pretende encontrar o locus amoenus da poesia, negandose, em princípio, a achar inspiração nas cidades modernas, que não são propícias aos vôos da imaginação poética: 

poesia. Língua e Literatura, n. 20, p. 81-102, 1992/1993.

Horriveis as cidades!

Vaidades e mais vaidades...

Nada de asas! Nada de poesia! Nada de alegria! ("Os Cortejos")

O poema "Rua de São Bento" pode ser lido pela isotopia da viagem, no caso, uma viagem marítima, já que encontramos, ao longo dele, vários signos pertencentes ao campo semântico de mar: navios de vela, naufrágios, uiara, ondas, porto.

Sabe-se que uma viagem simboliza a busca da verdade, da paz, da imortalidade; a procura e a descoberta de um centro espiritual. Simbolicamente, a viagem exprime, mais do que um deslocamento físico, um desejo de mudança interior, uma necessidade de experiências novas; uma aventura e uma procura de um tesouro ou de conhecimentos. Na mitologia chinesa, a viagem realiza-se no interior do ser humano, pois a viagem que é uma fuga de si mesmo sempre fracassará.

No poema "Rua de São Bento" a rua do título que, na época de Mário de Andrade, era o centro financeiro da capital paulista, para Marlene de Castro Correia (Op. cit.), funciona como metonímia da cidade de São Paulo em processo de industrialização e, por extensão, da sociedade capitalista e da civilização industrial. Em consonância com essa metonímia, ou complementando-a, temos a metáfora da rua; esta, no terceiro verso do poema, é comparada à uiara: "E os cantares da uiara rua de São Bento", numa clara indicação da atração que a metrópole moderna exerce sobre as pessoas e, no caso específico, sobre o sujeito-lírico. A figura da uiara, ou mãe-d'água, que corresponde à sereia européia, traz embutida a idéia de atração e perdição daquele que dela se enamora. ${ }^{2}$

O eu-lírico é, então, o navegante a deslocar-se pelo mar, a Rua de São Bento, vencendo as vagas - "estas duas ondas plúmbeas de casas plúmbeas" -, enfrentando as seduções do progresso, a uiara travestida de civilização - "as califórnias de uma vida milionária / numa cidade arlequinal" Note-se que a imagem da "cidade arlequinal", a cidade que se mascara em mil rostos e se divide em mil facetas, parece enfatizar a força de sedução da uiara, ocultando as faces destruidoras do progresso, que podem muito bem estar expressas nos seguintes versos: "Há leilão. Há feira de carnes brancas. Pobres arrozais! / A cainçalha... A Bolsa... As jogatinas..."

Mas o poeta, ainda não acostumado aos ares da civilização, sente-se oprimido, tragicamente dividido, despedaçado como a sua cidade:

(2) Vale observar que o mito da mãe-d'água é europeu, pertencente ao ciclo atlântico, posterior à poesia de Homero (CÂMARA CASCUDO, 1980). No Brasil dos séculos XVI e XVII, não existia a mãe-d'água atual, pois os indígenas, pela concepção que tinham da divindade, não podiam admitir, para as cis, as mães, origem de tudo, a função da sedução sexual. 

poesia. Língua e Literatura, n. 20, p. 81-102, 1992/1993.

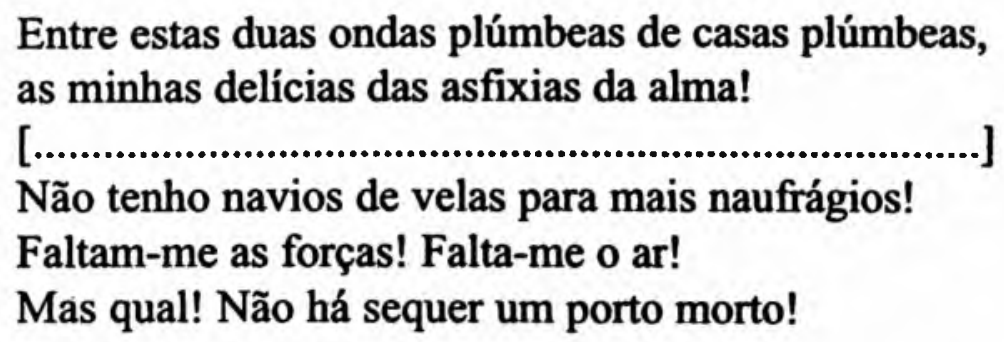

Observe-se o oxímoro do segundo verso da transcrição, funcionando como um significante do estraçalhamento do eu-lírico, atraído pela uiara, cujo cantar o sufoca. As "delícias das asfixias da alma" apontam para a negação do espaço da metrópole como gerador de poesia. Essa idéia o poeta já expressara antes, no poema "Os Cortejos": "Horríveis as cidades! / Vaidades e mais vaidades... / Nada de asas! Nada de poesia! Nada de alegria!"

Diante, então, da impossibilidade de o espaço civilizado funcionar como motor de sua inspiração, o poeta lança mão de um recurso muito moderno, que é o desabafo por meio do gracejo: "Can you dance the tarantella?" - "Ach! Ya" A saída por meio da piada é uma maneira de fazer eco ao adágio popular: $o$ que não tem remédio remediado está, e lembra-nos o famoso verso de Manuel Bandeira, em "Pneumotórax", que expressa o conformismo diante da fatalidade de uma doença incurável: “ - Então, doutor, não é possível tentar o pneumotórax? / - Não. A única coisa a fazer é tocar um tango argentino" A frase do poema de Mário de Andrade, que mistura o inglês ao italiano e ao alemão, sugere a babel moderna, o caos urbano que ensurdece o poeta e impede-o de exteriorizar sua inspiração.

Em "Rua de São Bento", explicita-se com nitidez uma disjunção do poeta em relação à cidade, expressa lingüisticamente pelo emprego da terceira e da primeira pessoa. A partir da sexta estrofe, presentifica-se uma das máscaras do poeta - a minha Loucura-, imagem recorrente em Mário de Andrade, que simboliza a inspiração poética e recupera uma das associações mais freqüentes no campo da poesia: inspiração poética / Loucura. Pois bem, no poema em estudo, o eu-lírico dirige-se a essa entidade, em terceira pessoa, e fala-lhe de um outro local - um locus amoenus - que seria a terra da poesia, distante, portanto, do estéril turbilhão da rua.

Na fala do eu-lírico à minha Loucura, ele a exorta a ter paciência, pois não é hora e lugar de manifestar-se; o seu locus não é o da metrópole, o seu é um locus amoenus, que está "muito-ao-longe do horizonte":

Minha Loucura, acalma-te!

Veste o water-proof dos tambéns!

Nem chegarás tão cedo

à fábrica de tecidos dos teus êxtases; 
telefone: Além, 3991...

Entre estas duas ondas plúmbeas de casas plúmbeas, vê, lá nos muito-ao-longe do horizonte, a sua chaminé de céu azul!

Vê-se, agora, que o propósito da viagem empreendida pelo eu- lírico é atingir a terra da poesia; há, portanto, bem distintos, um aqui (a cidade moderna) e um além (a terra da poesia). Somente lá a minha Loucura poderá manifestar-se. Do mesmo modo que há uma distanciamento entre o eu-lírico e a cidade moderna; entre a cidade moderna e o território da poesia; há uma distância entre o eu-lírico e os outros homens os tambéns. E a "diferença do sujeito-lírico diante dos indiferenciados [...] daqueles que se integram no sistema, massa uniforme, desindividualizada e acomodada" (CORREIA: Op. Cit.). Essa diferença explicitase, como lembra Correia, no poema "Os Cortejos", onde o eu-lírico assim se refere aos outros homens:
Estes homens de São Paulo, todos iguais e desiguais, quando vivem dentro dos meus olhos tão ricos, parecem-me uns macacos, uns macacos.

Mas, enquanto não chega ao "Além, 3991", a terra da poesia, convém vestir a máscara dos tambéns: "Veste o water-proof dos tambéns". A imagem do impermeável é retomada, como veremos, na "Paisagem N ${ }^{\circ} 3$ ": "A casa Kosmos não tem impermeáveis em liquidação", numa sugestão, talvez, da necessidade de se manter imune à emoção geradora da arte, tal qual os outros homens, uma vez que o eulírico se nega a aceitar o ambiente metropolitano como o locus poesiae.

A esse locus da poesia, que se situa "muito-ao-longe do horizonte", ele batiza de "fábrica de tecidos dos teus êxtases", de onde se destaca uma "chaminé de céu azul" Como se sabe, a tecelagem é um trabalho de criação, um parto. É símbolo do destino tudo o que entra no trabalho da fiação: tecido, fio, tear, fuso, roca. Tecer, além do significado de predestinar, com relação ao plano antropológico; de reunir realidades diversas, com relação ao plano cosmológico, carrega o significado de "criar, fazer sair de sua própria substância, exatamente como faz a aranha, que tira de si própria a sua teia" (CHEVALIER: 1993). Portanto, nada mais sugestivo para indicar o trabalho de poetar do que o símbolo da tecelagem, ainda mais quando o eu-lírico, como já demonstramos, sugere neste poema que a inspiração poética não virá do espaço urbano, da sua realidade objetiva, mas de um locus que se situa além e que parece ter espaço em seu próprio interior: a "fábrica de tecidos dos teus êxtases"

Na fábrica de tecidos, destaca-se uma chaminé de céu azul. É curioso constatar como se amplia o simbolismo dessas imagens usadas por Mário de Andrade, 

poesia. Língua e Literatura, n. 20, p. 81-102, 1992/1993.

que convergem todas para um mesmo ponto, como demonstraremos. Conforme nos ensina Chevalier (Op. Cit.), a chaminé é símbolo das vias de comunicação com os seres do alto. Seu simbolismo aproxima-se do simbolismo do eixo do mundo, "ao longo do qual descem os influxos celestes e as almas se elevam da terra. Ela liga os dois mundos entre si: a fumaça que dela se evola é o testemunho da existência de uma respiração e, portanto, de uma vida dentro da casa" Por outro lado, a cor que entra na composição da imagem - o azul - reforça a sugestão de mágica espiritualidade, que caracteriza o ato de poetar. Mais uma vez recorrendo a Chevalier, aprendemos que o azul, por ser a mais imaterial de todas as cores, imaterializa tudo aquilo que dele se impregna. $O$ azul é o caminho do infinito onde o real se transforma em imaginário. É desta cor o pássaro da felicidade, inacessível embora esteja tão próximo. Entrar no azul é fazer como Alice: passar para o outro lado do espelho, pois o azul é o caminho da divagação e, quando ele escurece, transforma-se no caminho do sonho. É o instante em que o pensamento consciente cede lugar ao inconsciente. Ora, concebendo-se o ato de poetar como um trabalho em que estranhas forças espirituais intervêm; ou, ainda, admitindo-se a antiga concepção de que existe um parentesco entre poesia e magia, a imagem da "fábrica de tecidos dos teus êxtases". com sua "chaminé de céu azul", funciona como uma espécie de senha, por meio da qual Mário de Andrade nos leva a embarcar com ele e empreender essa viagem de busca.

Embarcando na "Rua de São Bento", e seguindo em busca de um lugar em que a minha Loucura possa realizar-se, o eu-lírico confronta-se com a cidade que também como ele se mascara; e os dois promovem uma grande arlequinada, em que a falta de definição se torna explícita. Importante notar que o mascaramento da cidade, que se manifesta no clima, aparece logo no verso inicial do poema "Paisagem $N^{\circ} 1$ ": "Minha Londres das neblinas finas...", repetindo-se essa notação nas paisagens de $\mathrm{n}^{\circ} 2$ e 3 , sempre nos primeiros versos: "Escuridão dum meio-dia de invernia..."; "Chove? / Sorri uma garoa cor de cinza" Isso não ocorre na "Paisagem $\mathrm{N}^{\circ} 4$ " e o motivo será por nós sugerido quando tentarmos inserir o significado daquele poema no sentido mais amplo de nossa análise.

$\mathrm{Na}$ primeira parte do poema (as duas primeiras estrofes) que, com exceção do possessivo do primeiro verso - "Minha Londres das neblinas finas..." -, estrutura-se toda em terceira pessoa, faz-se a descrição da cidade, que se caracteriza (ou se descaracteriza) pela inconstância, ou até um certo paradoxo, do clima:

Minha Londres das neblinas finas...

Pleno verão. Os dez mil milhões de rosas paulistanas.

Há neves de perfumes no ar.

Faz frio, muito frio...

[.............................................]

O vento é como uma navalha

Nas mãos de um espanhol. Arlequinal... 
Há duas horas queimou Sol.

Daqui a duas horas queima sol.

No segundo movimento do poema (as três últimas estrofes), composto em primeira pessoa, o eu-lírico tenta autodefinir-se, procurando espelhar-se na cidade. Tanto é que a cidade parece ser a extensão de seus sentimentos, ou ele ser a extensão da cidade. Seus sentimentos oscilam conforme o clima:

Meu coração sente-se muito triste...

Enquanto o cinzento das ruas arrepiadas

Dialoga um lamento com o vento..."

Meu coração sente-se muito alegre!

Este friozinho arrebitado

Dá uma vontade de sorrir!

Veja-se a falta de caráter do eu-lírico expressa pela antítese triste / alegre. Essa descaracterização se acentua no final do poema, quando deixa de haver uma correspondência entre os sentimentos do eu- lírico e o clima da cidade, o que se revela na nova antítese - alacridade / lágrimas.

E sigo. E vou sentindo,

$\grave{A}$ inquieta alacridade da invernia,

Como um gosto de lágrimas na boca...

Percebe-se que o emprego da primeira pessoa, neste poema, é mais um mascaramento do eu-lírico em sua relação com a cidade. A primeira pessoa, no caso, oculta o deslocamento espiritual do sujeito-lírico e revela, subjacentemente, uma resistência em considerar o lugar da civilização e do progresso como o topos do poético.

Se na "Paisagem $\mathrm{N}^{\circ} 1$ " essa significação é subjacente, na "Paisagem $\mathrm{N}^{\circ} 2$ " apresenta-se claramente na própria estrutura do poema, o que nos leva a uma proposta de leitura que reconheça no texto dois locus: o aqui e o além. $\mathrm{O}$ aqui é a cidade de São Paulo, com sua realidade invernosa:

Escuridão dum meio-dia de invernia...

Marasmos... Estremeções... Brancos...

$O$ céu é todo uma batalha convencional de confetti brancos;

[.....<smiles>[AlH2]</smiles>

Os invernos de Paulicéia são como enterros de virgem...

[......................................... ] 

poesia. Língua e Literatura, n. 20, p. 81-102, 1992/1993.
Deus recortou a alma de Paulicéia num cor-de-cinza sem odor...;

com suas oficinas que destroem a saúde dos proletários e arruínam suas vidas:

Lá para as bandas do Ipiranga as oficinas tossem...

Todos os estiolados são muito brancos.

Com suas doenças e outros males advindos do progresso:

Mas os homens passam sonambulando...

E rodando num bando nefário, vestidas de eletricidade e gasolina, as doenças jocotoam em redor...

O aqui é, enfim, uma grande mascarada, uma grande função, em que o próprio eu-lírico assume a cabotinagem:

Grande função ao ar livre!

Bailado de Cocteau com os banulhadores de Russolo!

Opus 1921.

São Paulo é um palco de bailados russos.

Sarabandam a tísica, a ambição, as invejas, os crimes

e também as apoteoses da ilusão...

Mas o Nijinsky sou eu!

E vem a Morte, minha Karsavina!

Quá, quá, quá! Vamos dançar o fox-trot da desesperança, a rir, a rir dos nossos desiguais!

$\mathrm{Na}$ "grande função ao ar livre", que é a cidade de São Paulo, o eu-lírico, o grande cabotino, brinca com as referências históricas. Note-se que a referência a Cocteau pode apontar para uma possivel rejeição às estéticas de vanguarda, como o Futurismo, o Cubismo e o Dadaísmo, pelo sujeito-lírico que, naquele momento, esconde-se cabotinamente sob a máscara de um trovador que recusa o moderno espaço urbano como o locus poesiae. Ao assumir o papel de Nijinsky, que teve sua carreira interrompida por uma doença mental, o cabotino põe em cena a minha Loucura, que encontra a morte no tumulto da cidade grande. É sugestiva a relação dos elementos que dançam a sarabanda - formam uma enumeração meio caótica que peca (ou ganha) pela aparente falta de paralelismo semântico, como que a sugerir o caos urbano. E, mais uma vez, o eu-lírico opta pelo humor como fuga, à maneira do que fez em "Rua de São Bento". Curioso é que o gracejo, também aqui, faz-se por meio da referência a um tipo de dança: se !á, em "Rua de São Bento", ele 

poesia. Língua e Literatura, n. 20, p. 81-102, 1992/1993.

convida a dançar uma tarantella, aqui, em "Paisagem $\mathrm{N}^{\circ} 2$ ", incita a dançar um fox-trot: "Quá, quá, quá! Vamos dançar o fox-trot da desesperança / a rir, a rir dos nossos desiguais!"

Se o aqui é a cidade de São Paulo, com todos os seus males, o além é apresentado como uma terra sem males, onde reina a primavera. $\mathrm{Na}$ estrutura do poe$\mathrm{ma}$, esse locus amoenus, que comporia um segundo movimento, enquanto as referências à Paulicéia comporiam o primeiro, aparece aos olhos do leitor, primeiro, numa pequena chamada que se dá no último verso da primeira estrofe e que se repete no último da quinta estrofe, quase que à guisa de ritornelo: "Oh!, para além vivem as primaveras eternas!" Observe-se o tom emotivo do verso, diríamos, quase de saudade, como se, realmente, aquele lugar de refúgio da poesia fosse coisa do passado, estivesse prestes a desaparecer; depois, esse locus, na estrutura do poema, é indicado em uma estrofe completa:

Lembras-te? As barcarolas dos céus azuis nas águas verdes... Verde - cor dos olhos dos loucos!

As cascatas das violetas para os lagos...

Primaveril - cor dos olhos dos loucos!

A interrogação inicial é meio ambígua: "Lembras-te?". A quem interroga o sujeito-lírico? A estrofe anterior a essa, na qual ele fala dos invernos brancos da Paulicéia, termina com um verso de complicada exegese: "Italianinha, torna al tuo paese!" Mas não parece que a pergunta seja enderaçada à italianinha. Seria ao leitor? À minha Loucura? Mas, independente de encontrarmos uma resposta a essa questão, a estrofe traz elementos importantes para a leitura que estamos fazendo. Ela retoma o sentido da viagem, por meio do signo barcarola que, embora esteja dicionarizado como um tipo de canção romântica cantada pelos gondoleiros de Veneza (estaria aí uma relação com a italianinha?), não me parece ter sido usado nessa acepção, e traz o semantema de barco. Recupera, também, a idéia da minha Loucura: "Verde - cor dos olhos dos loucos! / Primaveril - cor dos olhos dos loucos!". Repete o signo azul, já usado em "Rua de São Bento", a respeito da chaminé "da fábrica de tecidos dos teus êxtases" e, por fim, enfatiza a idéia do locus amoenus, da terra sem males, por meio de uma descrição em que aparecem elementos da natureza pintada de cores apraziveis: "céus azuis nas águas verdes"; "verde"; "as cascatas das violetas para os lagos"; "Primaveril"

Lembremos que, dentro do simbolismo das cores, o verde assume grande importância. Dentre outras significações, temos a de que o verde é o despertar das águas primordiais e da vida, daí ser também a cor da esperança; é a cor da imortalidade, simbolizada pelos ramos verdes. Apesar de o verde ser o símbolo da razão os olhos de Minerva -, na Idade Média passou a símbolo do irracional, representando o brasão dos loucos. Portanto a terra da poesia, o topos da minha Loucura, ser primaveril, ser verde, condiz com a idéia de que a poesia, e a arte, de maneira 

poesia. Língua e Literatura, n. 20, p. 81-102, 1992/1993.

geral, tem virtude revigorante, tonificante e, ao mesmo tempo, poder tranqüilizador. Parece-nos ser esse o sentido do último solo de minha Loucura, nas "Enfibraturas do Ipiranga":

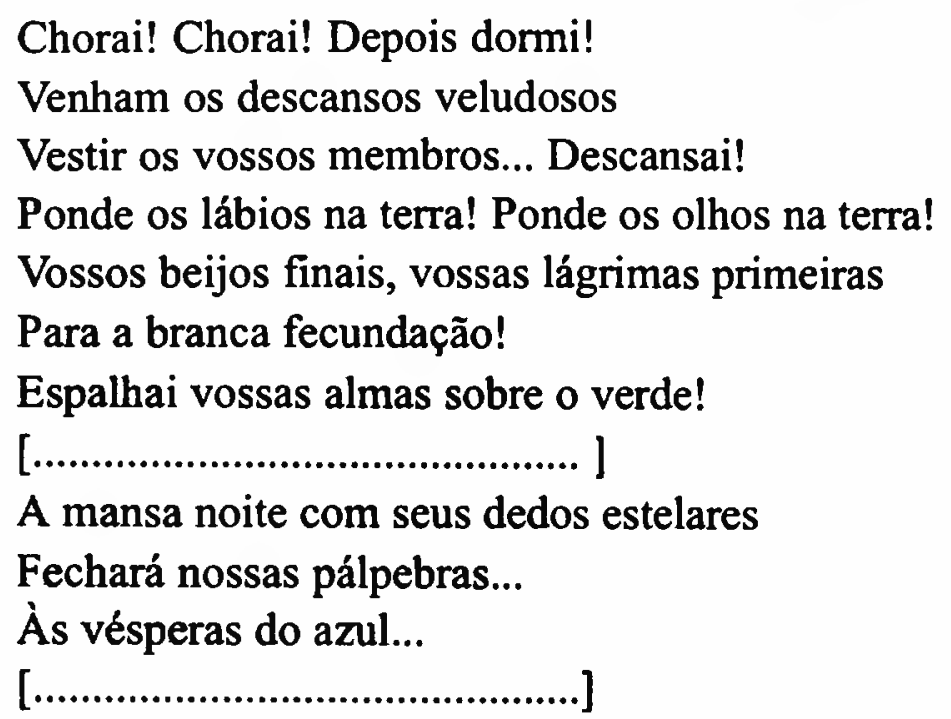

A leitura da "Paisagem $N^{\circ} 3$ " exige a consideração de elementos já trabalhados na "Rua de São Bento" e em "Paisagem $\mathrm{N}^{\circ} 2$ " Sugerimos para a leitura desse poema o reconhecimento de dois planos: o plano da cidade e o plano do poeta. A cidade, como nos poemas anteriormente estudados, aparece invernosa e, acima de tudo, arlequinal: "Chove? / Sorri uma garoa cor de cinza, / Muito triste como um tristemente longo..."

O que chamamos de plano do poeta apresenta o eu-lírico num movimento de mudança, que pode funcionar como um limite entre a atitude de afastamento radical em relação à cidade, constatada na "Rua de São Bento". e a total integração eu-lírico / cidade, que iremos investigar na "Paisagem $\mathrm{N}^{\circ} 4$ " Num primeiro momento, o sujeito-lírico assume a posição de mero espectador do cenário urbano:
A casa Kosmos não tem impermeáveis em liquidação...
Mas neste largo do Arouche
Posso abrir meu guarda-chuva paradoxal, Este lírico plátano de rendas mar...

Vemos novamente aqui a retomada da imagem do impermeável: "A casa Kosmos não tem impermeáveis em liquidação...", anteriormente usada em "Rua de São Bento": "Minha Loucura, acalma-te! / "Veste o water-proof dos tambéns!". Se entendermos o impermeável como um mecanismo de proteção do eu-lírico contra a contaminação do sentimento gerador do poético, como fizemos quando da análise da "Rua de São Bento", temos um eu-lírico que se propõe manter-se imparcial diante do espetáculo da metrópole moderna. Ante a falta de impermeáveis, tenta 

poesia. Língua e Literatura, n. 20, p. 81-102, 1992/1993.

ele o guarda-chuva; só que o guarda-chuva é paradoxal, pois que é um "lírico plátano de rendas mar..."

Ora, o guarda-chuva relaciona-se, simbolicamente, com a sombra, o encolhimento, a proteção. Portanto, abrigar-se sob um guarda-chuva significa fugir das responsabilidades, da realidade. Aceitar a proteção do guarda-chuva implica diminuição de dignidade, de independência e de potencialidade de vida. Se transferirmos esse simbolismo para a situação do eu-lírico no poema em questão, temos que proteger- se sob um guarda-chuva equivale, para o poeta, a não cumprir o seu papel social: interpretar a sociedade, ser seu porta-voz. Mas, no caso desse poema, o guarda-chuva é um "lírico plátano de rendas mar", daí ser paradoxal: o que foi feito para proteger, para imunizar, acaba não cumprindo sua missão, ao contrário, acaba por ser um atalho, através do qual o sujeito-lírico aproxima-se da cidade, sente seus miasmas, contamina-se.

A segunda estrofe do poema põe em cena, mais uma vez, a minha Loucura, desta vez, dialogando com o eu-lírico:

Ali em frente... - Mário, põe a máscara!

- Tens razão, minha Loucura, tens razão.

O rei de Tule jogou a taça ao mar...

Depois de reconhecer a impossibilidade de se proteger da sedução da cidade, e poeta é incitado a pôr a máscara com a qual poderá tentar entender aquele mundo novo. A referência ao rei de Tule sugere a necessidade da participação, da experiência pessoal, da vivência, enfím, para que o eu-lírico possa conseguir essa compreensão do espaço urbano, possa atingir o conhecimento desse outro mundo. Sabemos que Tule, nome dado pelos romanos provavelmente à Islândia, marcava o limite norte do mundo então conhecido; por isso simboliza o limite provisório do mundo, o desejo e a consciência do extremo; simboliza o limite extremo onde termina este mundo e começa o Outro Mundo, no qual se encontra o conhecimento supremo, ou revelação primordial, que não pode ser transferido por herança. Esse conhecimento sagrado, representado pela taça que o rei joga ao mar porque não pode ser objeto de doação, só poderá ser conseguido por uma experiência pessoal, uma intuição.

A compreensão do novo mundo a moderna cidade industrial - só será conseguida por aquele que for capaz de vivenciá-la, de penetrar em seus labirintos, de tornar-se um com ela, por isso a proposta da minha Loucura: que o poeta ponha a máscara, necessária a esse trabalho de conhecimento.

A terceira estrofe do poema se inicia com um verso que, à primeira vista, pode parecer contraditório: "Os homens passam encharcados..." pois dissemos anteriormente que a imagem do impermeável simbolizaria a proteção usada pelos que não eram poetas, para não se deixarem contaminar pela emoção geradora do fazer poético. E era exatamentè essa situação que marcava a diferença entre o poeta - aquele que sente, que é capaz de emocionar-se, aquele que tem os "olhos tão 
ricos" ("Os Cortejos"), e os outros homens, os "tambéns" ("Rua de São Bento"). Mas essa era a opinião do eu-lírico, antes, quando se sentia distante dos homens comuns. Contudo, como diz Marlene de Castro Correia (Op, cit.), "O percurso poético de Mário implicará minimizar a sua diferença, que passará a interpretar como empecilho ao seu anseio de integração na unidade" Transposto o limite, o poeta vai ver que os outros homens também são capazes de se deixar emocionar, de se deixar encharcar: "Os homens passam encharcados..."

A integração do eu-lírico ao plano da cidade permitirá que ele intervenha e cumpra sua função social: ajudar a melhorar esse ambiente hostil, esse topos da morte:

\section{(E si pusesse um verso de Crisfal No De Profundis?...) \\ De repente \\ Um raio de Sol arisco \\ Risca o chuvisco ao meio.}

A imagem do "raio de Sol" para mostrar o efeito da poesia sobre a sociedade é por demais sugestiva: os raios, ao simbolizar uma emanacão luminosa propagada de um centro, que pode ser o sol, o santo, o herói, o gênio, sobre outros seres, exprime uma fecundante influência material ou espiritual. Poderá, assim, esquentar, estimular e fecundar. Portanto um "raio de Sol" é capaz de clarear e alegrar o cinzento ambiente de morte da Paulicéia. Note-se que essa alegria, essa vida, nos é passada não só pelo nível do conteúdo, mas também pelo nível da expressão: a reiteração dos fonemas /i/ e /s/ enfatizam essa significação: "De repente / Um raio de Sol arisco / Risca o chuvisco ao meio"

O final de "Paisagem $\mathrm{N}^{\circ} 3$ " traz, assim, a superação da distância entre eulírico e cidade, que irá consumar-se em "Paisagem $\mathrm{N}^{\circ} 4$ ", poema no qual desaparece a primeira pessoa, $o$ indice lingüístico dessa separação. Ao manifestar-se quase que somente a terceira pessoa, é como se o mergulho do eu-lírico na cidade fizesse dela o eco de seus sentimentos, numa reencenação do mito de Narciso.

"Paisagem $\mathrm{N}^{\circ} 4$ ", a última das paisagens de Paulicéia Desvairada, camufla, como já dissemos, a presença do eu-lírico pelo emprego da terceira pessoa do discurso, com exceção dos versos de números vinte e um e vinte e dois, que aparecem com uma primeira pessoa do plural. Há, no entanto, outros índices lingüísticos que denunciam uma forte presença, da função emotiva, função centrada no emissor, tais como o ponto de exclamação e as reticências. Dos vinte e quatro versos que compõem o poema, somente quatro (aliás, dois, que se repetem) não terminam por esses dois signos de pontuação denunciantes do envolvimento emocional do sujeito-poético.

O poema é um retrato irônico-sentimental da cidade de São Paulo que, metonimicamente, passa a representar o próprio estado. Percebe-se que o senti- 
mento de paulistanidade do eu-lírico se manifesta numa visão que se esforça por ser crítica, daí o grande embate entre as forças da emoção e as forças da razão crítica. Por isso mesmo, essa visão tende a ser crítico-irônica. Nessa paisagem, ao contrário do que acontece nas outras três, não há a preocupação com a caracterização do clima invernoso da cidade, que tão bem retratava o caráter arlequinal do poeta e da cidade. Aqui, há um olhar sobre o dinamismo da cidade e a constatação das contradições decorrentes do progresso.

A primeira estrofe do poema, cujos versos se repetem integralmente para formar a terceira estrofe, descreve a cidade em seu dinamismo de cidade progressista:

Os caminhões rodando, as carroças rodando, Rápidas as ruas se desenrolando, Rumor surdo e rouco, estrépitos, estalidos...

E o largo coro de ouro das sacas de café!...

Observe-se que a significação de movimento, de dinamismo e de progresso, é enfatizada por expressivos recursos estilísticos, como a aliteração de fonemas oclusivos, mas principalmente de fonemas vibrantes, e o emprego do genúndio. No entanto o progresso traz em seu bojo inúmeras contradições, principalmente em países como o Brasil, que seguiu queimando etapas e chega ao século XX descaracterizado, misturando passado e presente. Essa descaracterização nos é mostrada pela irônica antítese do primeiro verso - "Os caminhões rodando, as carroças rodando" -, em que caminhões e carroças, convivendo lado a lado, parecem denunciar e prognosticar uma situação paradoxal que perdurará por muitos anos no país. A imagem do último verso do quarteto - "E o largo coro de ouro das sacas de café!..." - enfatiza essa situação paradoxal, que permite conviverem lado a lado a riqueza e a pobreza, o progresso e o subdesenvolvimento.

À descaracterização determinada pelo progresso vem somar-se a des- caracterização imposta pela interferência estrangeira que cria e amplia o esfacelamento cultural: "Na confluência o grito inglês da São Paulo Railway..." Seguemse alguns versos que parecem apontar para o momento histórico das dificuldades dos produtores de café, aristocracia à qual se ligava Mário de Andrade, não pela situação sócio-econômica, mas pela formação humanista, relação que contribui para a crise de não-identidade do poeta.

$O$ quinto verso da segunda estrofe "Muito ao longe o Brasil com seus braços cruzados" - denuncia o mito ainda hoje alimentado no país (mito que não deixa de alicerçar-se na realidade) de que São Paulo, com o seu progresso e sua riqueza, carrega nas costas o resto do Brasil, que cruza os braços.

A quarta estrofe parece sugerir um contexto de luta, em que São Paulo acaba vitorioso pelo trabalho e pela riqueza. Mas a quinta estrofe introduz um forte componente irônico por meio do verso inicial - "E a coroação com os próprios 

poesia. Língua e Literatura, n. 20, p. 81-102, 1992/1993.

dedos!" -, em que a metonímia dedos por mãos corrobora o tom crítico-sarcástico do todo o poema. Os três versos finais desta estrofe,

Ponhamos os (Vitória!) colares de presas inimigas!

Enguirlandêmo-nos de café-cereja!

Taratá! E o pean de escámio para o mundo!

trabalham elementos nacionalistas: "colares de presas inimigas" que sugere a antropofagia de nossos índios; e "café-cereja", que aponta para um produto tipicamente brasileiro e responsável pela grandeza do estado de São Paulo. Esses elementos funcionam como contraponto da ressonância estrangeira no país, denunciando o esforço do eu-lírico em entender e encontrar o verdadeiro caráter nacional. Note-se que o emprego da primeira pessoa do plural: "Ponhamos" e "Enguirlandêmo-nos", que inclui disfarçadamente o sujeito-poético, soa como um grito de nacionalismo, como um movimento em prol da definição do caráter brasileiro. Mas o último verso quebra, pela ironia, pelo chiste, o tom de pretensa seriedade imposto de vez em quando ao poema. A onomatopéia - "Taratá", juntamente com o obscuro "pean" (pum?) "de escárnio para o mundo" celam o tom de blague que dialoga com o tom de seriedade ao longo de todo o texto.

O poema encerra-se por um verso com jeito de chave de ouro, que mescla ironia com seriedade: "Oh! Este orgulho máximo de ser paulistamente!!!" Note-se que é difícil, senão impossível, determinar o tom desse verso. $\mathrm{O}$ eu-lírico participa do orgulho quatrocentão do paulista, ou, como bom poeta moderno e modernista, ironiza esse orgulho como elemento passadista? A construção sintática "ser paulistamente" - que é meio esdrúxula, pois a norma seria ser paulista - e o ponto de exclamação triplicado que a segue, exagerando o envolvimento emotivo e forçando a ressonância irônica, nos levam a duvidar do tom de seriedade do texto.

$O$ certo é que todo o poema se mascara de ambigüidade, mas deixa explícita a aceitação do espaço citadino moderno como motor da produção lírica. $O$ poeta termina sua viagem, iniciada em "Rua de São Bento", numa sugestão de que a poesia não mais necessita de um locus amoenus; a partir de agora, o espaço urbano, seu último porto, e a realidade cotidiana substituirão esse locus, adquirindo estatuto poético. Assim, em Mário de Andrade, e a partir dele, a relação do eu-lírico com esse novo espaço não será sempre de tranqüila aceitação; o poeta manterá um distanciamento crítico, de modo que o seu discurso poético sobre a cidade moderna revelará quase sempre um estado de tensão, que se resolverá por uma crítica acerba, ou encontrará sua forma de expressão na ironia, no sarcasmo e, muitas vezes, no humor e na piada.

\section{Conclusão}

Há, no poema "Rua de São Bento" três versos muito curiosos: "Há navios de vela para os meus naufrágios!" (v. 2) / "Não tenho navios de vela para mais 

poesia. Língua e Literatura, n. 20, p. 81-102, 1992/1993.

naufrágios!" (v. 9) / "Faltam-me as forças! Falta-me o ar!" (v. 10) / "Mas qual! Não há sequer um porto morto!". Os três assim em destaque, mas relacionados ao contexto maior do poema, impressionam pela desesperança que transmitem. O primeiro verso parece convidar à aventura; há quase a oferta da embarcação. O segundo já sugere uma grande desilusão e uma profunda desesperança: é como se quaisquer outras tentativas fossem inúteis. Os dois versos juntos nos levam a acreditar que o sujeito-lírico não se importaria de sofrer, de naufragar, desde que ainda houvesse possibilidades de sua busca ser levada a bom termo. Os dois versos finais sugerem a total desilusão, a desistência de qualquer busca, situação que se altera em outros poemas.

Conforme vimos ao longo desta análise, o que o eu-lírico buscava em sua viagem era um lugar onde a minha Loucura pudesse se manifestar; ele buscava o locus amoenus e rejeitava a cidade industrializada como uma resposta a sua busca. Constatamos que essa rejeição vai aos poucos diminuindo, até desaparecer completamente na absorção do sujeito-lírico pela cidade, registrada em "Paisagem $\mathrm{N}^{\circ} 4$ "

Mas essa relação tumultuada entre poeta e civilização, entre poeta e progresso, entre poeta e cidade grande, manifestada por Mário de Andrade e por alguns escritores estrangeiros do início do século, fíca como herança na literatura ocidental e, particularmente, na literatura brasileira, onde podemos encontrar inúmeros exemplos.

Temos Manuel Bandeira e seu grito desesperado contra o progresso e sua pretensa beleza: "Diabo leve quem pôs bonita a minha terra!" ("Minha terra"). Ou Vinícius de Moraes e sua descrição impressionista da chegada do progresso ao Novo México: "Terra seca árvore seca / E a bomba de gasolina / Casa seca paiol seco / E a bomba de gasolina / [........] / E a bomba de gasolina / E a bomba de gasolina / E a bomba de gasolina / E a bomba de gasolina..." ("O ônibus Grayhound atravessa o Novo México"). E mais, a revolta ecológica de Mário Quintana: "Onde estão os meus verdes? / Os meus azuis? / O Arranha-Céu comeu!" ("Poema de circunstância"). Ou ainda a fina ironia de Carlos Drummond de Andrade em "Infatigável":

O progresso não recua.

Já transformou esta rua

em buraco.

E o progresso continua.

Vai abrir neste buraco

outra rua.

Afinal, da nova rua,

O progresso vai compor

outro buraco. 
Mas a verdade é que em nenhum desses poetas brasileiros encontramos aquela espécie de obsessão demonstrada por Mário de Andrade em Paulicéia Desvairada. Em nenhum outro, na literatura brasileira, descobrimos aquele lançar de olhos angustiado e, ao mesmo tempo, questionador e irônico, sobre sua cidade natal, como descobrimos em Mário de Andrade sobre a São Paulo dos anos vinte. Os cinco poemas que tentamos analisar neste trabalho nos revelaram, no entanto, que, no cabotino poeta da Paulicéia, o conflito parece se resolver pela aceitação da cidade com todos os seus problemas, sem que ele abandone sua inevitável postura irônica. E, se nos aventurarmos mais pela obra poética de Mário, encontraremos, quase fechando o Lira Paullistana, o poema "Quando eu morrer" que, à parte o humor e a intenção irônica do poeta, $e$ as interpretações que associam o retalhamento do eu-lírico ao retalhamento simbólico do boi na manifestação folclórica do Bumbameu-boi, temos uma declaração de amor do poeta a sua cidade, corroborando o que acabamos de demonstrar neste trabalho.

\section{REFERENCIAS BIBLIOGRÁFICAS E BIBLIOGRAFIA CONSULTADA}

ANDRADE, Mário de. Poesias completas: Mário de Andrade; ed. Crítica de Diléa Zanotto Manfio. Belo Horizonte: Itatiaia; São Paulo: EDUSP, 1987. 535 p.

. Do cabotinismo. In: _. O empalhador de passarinhos. 3 ed. São Paulo: Martins; Brasília: INL, 1972. p. 77-81.

BENJAMIM, Walter. Charles Baudelaire: um lirico no auge do capitalismo. Trad. José Carlos Martins Barbosa e Hémerson Alves Baptista. 2 ed. São Paulo: Brasiliense, 1991. (Obras escolhidas III).

CHEVALIER, Jean \& GHEERBRANT, Alain. Dicionário de simbolos. Trad. Vera da Costa e Silva [et al.]. 7 ed. Rio de Janeiro: José Olympio, 1993.

CORREIA, Marlene de Castro. A moderna lírica brasileira: Mário de Andrade. Tempo Brasileiro. Poesia sempre. Rio de Janeiro, n. 83, p. 150-178, out/dez. 1985.

FACIOLI, Valentim. São Paulo capital Brasil (Mário de Andrade e a cidade de São Paulo: aspectos). Trabalho mimeografado.

FRIEDRICH, Hugo. Estrutura da lírica moderna. Trad. Marise M. Curioni. 2 ed. São Paulo: Duas Cidades, 1991. 349 p.

KNOLL, Victor. Paciente arlequinada: uma leitura da obra poética de Mário de Andrade.

São Paulo: Editora Hucitec em convênio com a Secretaria de Estado da Cultura, 1983. $261 \mathrm{p}$.

LOPEZ, Telê Porto Ancona. Mário de Andrade: ramais e caminho. São Paulo: Duas Cidades, 1972, $267 \mathrm{p}$.

PAES, José Paulo. Cinco livros do Modernismo brasileiro. Estudos Avançados. São Paulo, v. 2, n. 3, p. 88-106, set./dez. 1988.

ROSENFELD, Anatol. Mário e o cabotinismo. In: Texto / contexto. 4 ed. São Paulo: Perspectiva, 1969, p. 185-200. 

poesia. Língua e Literatura, n. 20, p. 81-102, 1992/1993.

ABSTRACT: The reading of the following poems by Mário de Andrade: "Rua de São Bento" "Paisagem $\mathrm{N}^{\circ} 1$ " "Paisagem $\mathrm{N}^{\circ} 2^{\prime \prime}$ "Paisagem $\mathrm{N}^{\circ} 3^{\prime \prime}$ and "Paisagem $\mathrm{N}^{\circ} 4$ " suggests to us a search of a locus poesiae by the lyrical self, who rejects the modern city as this locus. In a dialectics of attraction and repulse, the lyrical self accepts in the end the metropolis as the territory of "minha Loucura" and reaches the point of integrating himself in it.

Key-Words: metropolis, locus poesiae, attraction, repulse. 